\title{
PENJAMINAN MUTU DI PRODI PENDIDIKAN SEJARAH FIS UNIVERSITAS NEGERI MEDAN DALAM MENGHADAPI REVOLUSI INDUSTRI 4.0
}

\author{
Lukita Ningsih, Najuah, Ricu Sidiq, Arfan Diansyah \\ Email : Najuah@unimed.ac.id \\ Jurusan Sejarah Universitas Negeri Medan
}

\begin{abstract}
Abstrak
Penulisan makalah ini untuk memaparkan penjaminan mutu di Prodi Pendidikan Sejarah FIS UNIMED dalam menghadapi revolusi industri 4.0. dengan latar belakang Arus globalisasi sudah tidak terbendung masuk ke Indonesia. Disertai dengan perkembangan teknologi yang semakin canggih, dunia kini memasuki era revolusi industri 4.0. Menghadapi tantangan tersebut, pengajaran di perguruan tinggi pun dituntut untuk berubah, termasuk dalam menghasilkan dosen berkualitas bagi generasi masa depan.Diperlukan upaya sadar daripentingnya upaya sadar dari institusi untuk meningkatkan kualitas dalam menjawab tantangan kemajuan teknologi di era revolusi industri 4.0 Tulisan ini termasuk dalam jenis deskriptif eksploratif dengan metode studi kepustakaan dan studi kasus. Hasil menunjukkan bahwa Prodi Pendidikan Sejarah telah melakukan berbagai upaya dalam upaya untuk meningkatkan mutu prodi pendidikan sejarah abtara lain dengan penerapan 6 tugas KKNI, Penerapan model Blended leraning dan pengadaan tes komprehensif online yang dilakukan dnegan menggunakan media online.
\end{abstract}

Kata Kunci: Penjaminan mutu, Prodi Pendidikan Sejarah, Universitas Negeri Medan, Menghadapi, Revolusi Industri 4.0

\section{Pendahuluan}

Arus Globalisasi telah nyata masuk ke Indonesia disertai dengan perkembangan teknologi yang semakin canggih dari masa ke masa. Dunia kini memasuki era industri 4.0 yakni menekankan pola digital economy, artificial intelligence, big data, robotic, dan lain sebagainya atau dikenal dengan fenomena disruptive innovation. Revolusi industri 4.0 secara umum diketahui sebagai perubahan cara kerja yang menitikberatkan pada pengelolaan data, sistem kerja industri melalui kemajuan teknologi, komunikasi dan peningkatan efisiensi kerja yang berkaitan dengan interaksi manusia. Data menjadi kebutuhan utama organisasi dalam proses pengambilan keputusan organisasi yang di dukung oleh daya komputasi dan sistem penyimpanan data yang tidak terbatas.

Dalam era globalisasi ini perkembangan Teknologi Informasi dan Komunikasi semakin berkembang pesat. Perkembangannya secara fundamental telah membawa perubahan yang 
signifikan dalam percepatan dan inovasi penyelenggaraan pendidikan di berbagai negara. Dalam dunia pendidikan, perkembangan Teknologi Informasi dan Komunikasi mulai dirasa mempunyai dampak yang positif, karena dengan berkembangnya Teknologi Informasi dan Komunikasi dalam dunia pendidikan mulai memperlihatkan perubahan yang cukup signifikan. Pesatnya perubahan di era revolusi industri 4.0 perlu segera diantisipasi. Bentuk antisipasi yang dilakukan diantaranya menyusun berbagai kebijakan yang mendukung perubahan tersebut. Masalah utama yang harus segera diantisipasi adalah daya saing sumber daya manusia, tingginya angka pengangguran tingkat sarjana, hingga kapasitas pekerja yang belum terampil menuntut perguruan tinggi lebih menyiapkan lulusan yang bisa bersaing di dunia kerja. Menghadapi tantangan tersebut, pengajaran di perguruan tinggi pun dituntut untuk berubah, baik dari sisi kualitas dosen, kurikulum, sarana dan prasarana dan mahasiswa sebagai outcomes dari sistem pembelajaran di perguruan tinggi.

Perguruan tinggi harus mulai mampu mengubah kurikulum sesuai dengan tantangan zaman yang dihadapi, Kementerian RistekDikti menjelaskan ada lima elemen penting yang harus menjadi perhatian dan akan dilaksanakan oleh Kemenristekdikti untuk mendorong pertumbuhan ekonomi dan daya saing bangsa di era Revolusi Industri 4.0, yaitu: pertama, Persiapan sistem pembelajaran yang lebih inovatif di perguruan tinggi seperti penyesuaian kurikulum pembelajaran, dan meningkatkan kemampuan mahasiswa dalam hal data Information Technology (IT), Operational Technology (OT), Internet of Things (IoT), dan Big Data Analitic, mengintegrasikan objek fisik, digital dan manusia untuk menghasilkan lulusan perguruan tinggi yang kompetitif dan terampil terutama dalam aspek data literacy, technological literacy and human literacy.

Kedua, Rekonstruksi kebijakan kelembagaan pendidikan tinggi yang adaptif dan responsif terhadap revolusi industri 4.0 dalam mengembangkan transdisiplin ilmu dan program studi yang dibutuhkan. Selain itu, mulai diupayakannya program Cyber University, seperti sistem perkuliahan distance learning, sehingga mengurangi intensitas pertemuan dosen dan mahasiswa. Cyber University ini nantinya diharapkan menjadi solusi bagi anak bangsa di pelosok daerah untuk menjangkau pendidikan tinggi yang berkualitas. 
Ketiga, Persiapan sumber daya manusia khususnya dosen dan peneliti serta perekayasa yang responsive, adaptif dan handal untuk menghadapi revolusi industri 4.0. Selain itu, peremajaan sarana prasarana dan pembangunan infrastruktur pendidikan, riset, dan inovasi juga perlu dilakukan untuk menopang kualitas pendidikan, riset, dan inovasi.

Keempat, Terobosan dalam riset dan pengembangan yang mendukung Revolusi Industri 4.0 dan ekosistem riset dan pengembangan untuk meningkatkan kualitas dan kuantitas riset dan pengembangan di Perguruan Tinggi, Lembaga Litbang, LPNK, Industri, dan Masyarakat. Dan kelima, Terobosan inovasi dan perkuatan sistem inovasi untuk meningkatkan produktivitas industri dan meningkatkan perusahaan pemula berbasis teknologi.

Program Studi sebagai pelaksana pembelajaran juga harus mampu menyesuaikan pembelajarannya dengan memanfaatkan kemajuan teknologi komunikasi informasi yang sedang berkembang dan banyak dimanfaatkan oleh mahasiswa. Berangkat dari kenyataan ini, ada beberapa kebijakan dari program studi pendidikan sejarah Fakultas ilmu sosial universitas negeri medan dalam upaya menghadapi revolusi industri 4.0

\section{Pembahasan}

\subsection{Pembelajaran berbasis 6 Tugas KKNI sebagai solusi menghadapi era Revolusi industri 4.0}

Revolusi industri 4.0 telah merubah perwajahan dunia dimana teknologi informasi telah menjadi basis dalam kehidupan manusia. Segala hal menjadi tanpa batas (borderless) dengan penggunaan daya komputasi dan data yang tidak terbatas (unlimited) karena dipengaruhi oleh perkembangan internet dan teknologi digital yang masif sebagai tulang punggung pergerakan dan konektivitas manusia dan mesin. Menjawab tantangan tersebut Universitas Negeri Medan mengambangkan kurikulumnya dengan menyusun standar perkuliahan KKNI. Kurikulum KKNI memiliki 4 poin inti yakni pengenalan ICT, menganalisis big data lewat literasi, menanamkan komunikasi terutama komunikasi dalam bahasa inggris dan yang terakhir adalah pembentukan sikap Dimana mahasiswa dibina melalui enam cara yang disebut 6 tugas, yakni; tugas rutin, critical book report, critical journal report, rekayasa ide, mini research dan project. Keenam tugas ini menjadi 
pola baru dalam proses perkuliahan yang diterapkan oleh dosen pada semester gasal tahun akademik 2016/2017. Hal inipun berlaku di Prodi Pendidikan Sejarah.

Tugas rutin merupakan tugas yang dilakukan pada setiap pertemuan. Bentuknya ada berbagai macam tergantung kepada dosen yang mendesain mata kuliah tersebut. Misalnya dalam bentuk makalah, tulisan, bahan tayang, dan sebagainya. Sedangkan critical book report yaitu mahasiswa mengkaji buku berdasarkan konsep atau teori yang dipelajari dalam suatu mata kuliah untuk menentukan critical position yang melakukan kajian. Prosesnya, dosen akan menetapkan buku utama dan buku pendukung, kemudian mahasiswa wajib berkelompok dalam proses pemahaman tetapi kemudian melaporkan hasil kritikal buku tersebut secara mandiri. Sementara itu, critical journal report ialah tugas dimana mahasiswa mereview semua komponen suatu laporan riset atau journal secara kritis dengan tujuan utama menemukan keunggulan dan kelemahan dari suatu riset atau journal serta menampilkan saran yang relevan untuk mempertahankan kekuatan dan mengatasi kelemahan riset atau jurnal tersebut. Pada tahap ini dosen akan menetapkan artikel dalam jurnal atau laporan hasil penelitian untuk direview. Jika mahasiswa memilih sendiri maka harus memperoleh persetujuan dosen. Mahasiswa dapat menggunakan artikel lain untuk melengkapi argumentasi. Kemudian mahasiswa wajib berkelompok saat proses pemahaman, tetapi melaporkan hasil harus secara mandiri.

Rekayasa ide, Pada tugas ini, dosen bersama mahasiswa mendiskusikan dan menetapkan cakupan ide-ide yang dapat direkayasa. Mahasiswa wajib membentuk kelompok berdasarkan kesamaan atau kemiripan ide yang akan direkayasa tetapi melaporkan hasil secara sendiri. Ide tersebut berupa turunan ide atau konsep baru dari ide yang sudah ada dan ide baru itu diprediksi berlaku dalam konteks sosial, sedangkan tugas Mini research merupakan tugas yang dikerjakan dengan cara mahasiswa dan dosen mendiskusikan dan menetapkan topik riset yang relevan. Apabila mahasiswa memilih topik sendiri harus mendapat persetujuan dari dosen. Selanjutnya mahasiswa wajib bekerja berkelompok dalam rangka menyusun rancangan mini research tetapi melaporkan hasil secara mandiri. Mini riset tersebut minimal harus mencakup pertanyaan hipotesis, teori, instrumen, pengumpulan data, analisis data, dan simpulan.

Yang terakhir yakni, mahasiswa Unimed harus mampu membuat project yang menghasilkan model, atau produk yang memiliki nilai etika, estetika, sosial, budaya, dan ekonomi. Tugas ini 594 | Seminar Nasional Sejarah ke 4 Jurusan Pendidikan Sejarah Universitas Negeri Padang 
menuntut mahasiswa untuk mampu menerapkan transfer pengetahuan demi pemecahan masalah kemudian mengomunikasikan hasilnya.

Dalam melakukan tugas-tugas tersebut, mahasiswa dilarang melakukan plagiat. Unimed akan memberikan sanksi yang berat bagi tindakan plagiat. Tujuannya adalah agar mahasiswa semakin berkualitas. Apabila terbukti bahwa yang penyelesaian tugas dilakukan oleh pihak lain maka tugas dibatalkan dan nilai mahasiswa yang bersangkutan berstatus mengulang pada mata kuliah dimaksud. Jika dilakukan oleh mahasiswa Unimed maka kepada kedua pihak dikenakan sanksi yang sama. Dan jika mahasiswa melakukan plagiat baik sebahagian maupun semuanya maka tugas dibatalkan dan nilai mahasiswa yang bersangkutan berstatus mengulang pada mata kuliah tersebut ditambah dengan skorsing selama 1 (satu) semester.

Dalam pelaksanaan pembelajaran di Prodi Pendidikan Sejarah selain mengikuti ketentuan 6 tugas KKNI Universitas Negeri Medan, juga mengikuti kebijakan dalam penyelenggaraan perkuliahan dengan blended learning.

\subsection{Penerapan Blended Learning Dalam Mata Kuliah Di Prodi Pendidikan Sejarah Dalam Menghadapi Revolusi Industri 4.0}

Model pembelajaran blended learning merupakan jenis pembelajaran yang menggabungkan pengajaran klasik (face to face) dengan pengajaran online. Menurut Elenena Mosa dalam Rusman, (2011:242) menyampaikan bahwa yang dicampurkan adalah dua unsur utama, yakni pembelajaran dikelas (classroom lesson) dengan online learning. Model pembelajaran blended learning ini sangat cocok digunakan di era revolusi industri ini, dimana mahasiswa sebagai bagian dari kaum milenial kini kurang menyukai pertemuan di kelas dan cenderung menghindarinya. Dengan penggunaan model ini, pembelajaran tidak hanya dapat dilakukan di dalam kelas pada saat jam pelajaran tetapi pembelajaran dapat juga dilakukan diluar jam pelajaran yaitu dengan menggunakan media online dengan ketentuan yang telah disepakati. Ada berbagai media online yang dapat digunakan oleh dosen namun yang digunakan di Prodi Pendidikan Sejarah untuk saat ini adalah terbatas pada SIPDA, Edmodo dan Google Classroom.

Penggunaan Model blended learnaing dengan media online ini telah nyata membantu mahasiswa dalam perkuliahannya. Misalnya saja memudahkan mahasiswa untuk berdiskusi baik dengan 
mahasiswa lain yang mengambil mata kuliah yang sama, maupun dengan dosen yang memiliki keterbatasan waktu. ,manfaat lainnya adalah khususnya dalam mengumpulkan 6 tugas KKNI, dimana cara ini erupakan cara yang efektif, efisien dan ekonomis. Dimana mahasiswa dapat mengumpulkan tugas darimanapun dan tanpa harus mengumpulkan hardcopy yang juga turut membantu perekonomian mahasiswa dan penjagaan pelestarian lingkungan hidup dnegan melakukan penghematan kertas. Terdapat nilai edukasi tinggi yang harus dimiliki oleh mahasiswa dalam model ini, yaitu disiplin, jujur, dan peka terhadap perkembangan revolusi industri 4.0 .

Model dan media ini juga membantu dosen dalam melaksanakan tugasnya, dimana dosen dengan mudah dapat memeriksa tugas mahasiswa dimanapun karena media online telah terpasang di android dosen masing-masing sesuai dengan mata kuliahnya sehinmgga tidak perlu membawa hasil tugas mahasiswa tersebut. Dosen juga dapat dengan mudah berbagi materi kepada mahasiswa dan mendapatkan respon mahasiswa terhadap materi tersebut. Dan berbagai manfaat lain yang efektif, efisien dan ekonomis namun ilmiah.

\subsection{Contoh Penerapan 6 Tugas KKNI Mata Kuliah Metodologi penelitian Pendidikan Sejarah dengan model Blended Learning}

Mata Kuliah ini merupakan mata kuliah wajib bagi mahasiswa Jurusan Pendidikan Sejarah dan merupakan salah satu mata kuliah dalam KDBK Pembelajaran. Mata kuliah ini membekali mahasiswa jurusan pendidikan sejarah untuk dapat menyusun proposal penelitian pendidikan. Mata kuliah ini mengkaji tentang hakikat penelitian pendidikan, jenis-jenis penelitian pendidikan hingga penyusunan proposal penelitian pendidikan yang dilakukann secara bertahap dalam arahan dan bimbingan tim dosen pemgampu. Semaksimal mungkin matakuliah ini berupaya memberi metodologi penelitian pendidikan sejarah, sehingga mampu bersikap dan mengimplementasikannya sebagai bagian dari kompetensi yang diharapkan dari seoarang calon sarjana pendidikan sejarah yang kompeten dan profesional.

Mata kuliah ini bertujuan untuk meningkatkan kompetensi mahasiswa dalam memahami hakikat dan konsep dasar penelitian pendidikan sejarah, menganalisis berbagai jenis penelitian pendidikan sejarah, menganalisis berbagai permasalahan dalam pembelajaran sejarah di sekolah, menyusun proposal pebnelitian pendidikan sejarah dengan benar, merekomendasikan solusi 596 | Seminar Nasional Sejarah ke 4 Jurusan Pendidikan Sejarah Universitas Negeri Padang 
permasalahan dalam pembelajaran sejarah di sekolah secara mutakhir dalam era revolusi industri 4.0 dan merancang seminar proposal penelitian pendidikan sejarah. Sehingga materi dalam matakuliah ini dibatasi pada : Hakikat dan konsep dasar penelitian pendidikan, jenis-jenis penelitian Pendidikan sejarah, Unsur-unsur Bab I dalam proposal penelitina pendidikan, Menyusun Bab I proposal penelitina pendidikan, Unsur-unsur Bab II dalam proposal penelitina pendidikan, Unsur-unsur Bab III dalam proposal penelitina pendidikan, Menyusun Bab III proposal penelitina pendidikan, Menyusun bab IV dan V untuk hasil penelitian pendidikan sejarah, Menganalsiis berbagai permasalahan dalam pembelajaran sejarah di sekolah melalui kegiatan mini riset, merekomendasikan solusi permasalahan dalam pembelajaran sejarah di sekolah dengan membuat proposal penelitian bidang pendidikan sejarah sesuai dengan permasalahan yang ditemukan sesuai dengan panduan penulisan yang disarankan, Menyusun Bab II proposal penelitina pendidikan dan merancang seminar proposal penelitian pendidikan sejarah

Pendekatan pembelajaran yang digunakan adalah scientific learning dengan model pembelajaran problem project based learning, blended learning, dan workshop project learning dan literasi berbasis digital dan non digital,. Beberapa informasi yang dijadikan bahan pertimbangan keberhasilan mahasiswa dalam perkuliahan ini adalah kehadiran, partisipasi selama perkuliahan, 6 tugas rutin, dan penilaian uji formatif meliputi Uji tengah semester dan uji akhir semester

Dalam perkuliahan pada mata kuliah ini telah menggunakan media online Edmodo untuk kegiatan online learning meliputi kegiatan diskusi, pemberian materi, pemberian tugas khsusnya 6 tugas KKNI, pemberian kuis ataupun tes formatif, dan pemilihan. Berikut adalah beberapa gambar penerapan Blended Learning dengan media online edmodo dalam mata kuliah metodologi penelitian pendidikan sejarah.
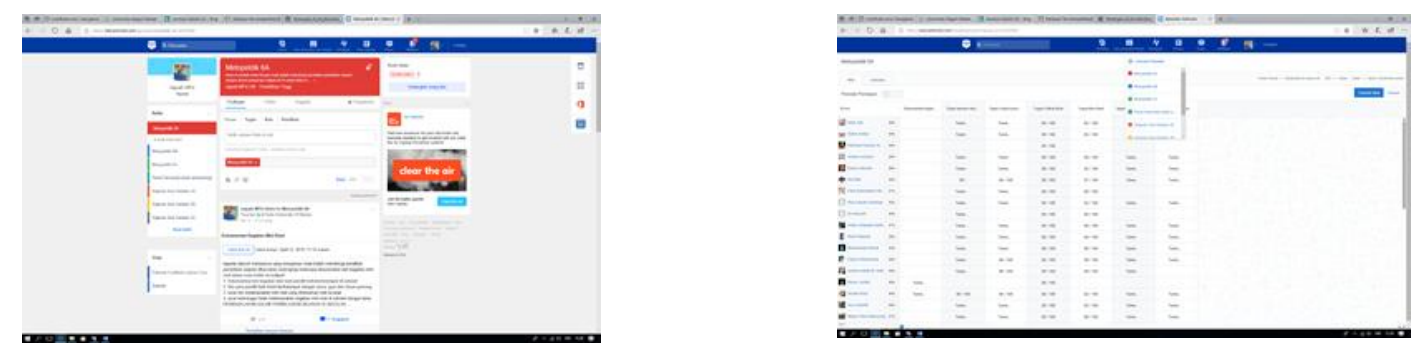

\subsection{Tes Komprehensif Online untuk Meningkatkan Mutu di Prodi Pendidikan Sejarah}

597 | Seminar Nasional Sejarah ke 4 Jurusan Pendidikan Sejarah Universitas Negeri Padang 
Tes Komprehensif merupakan ujian terakhir sebelum seorang mahasiswa berhak menyandang gekar sarjana, ujian ini untuk mengetahui pemahaman dan kemampuan mahasiswa mengenai bidang yang ditekuninya selama menempuh pendidikan di universitas. Prodi Pendidikan Sejarah FIS UNIMED, Tes komprehensif selian dilakukan di tingkat universitas, tes juga dilakukan di tingkat prodi. Hal ini dilakukan untuk meningkatkan mutu prodi. Tes komprehensif mulai januari 2019 telah dilakukan secara online yang dikelola oleh Laboratorium Komputer Sejarah.

Ada berbagai ketentuan yang berlaku agar mahasiswa dapat mengikuti tes ini. Dalam pelaksanaannya, Sebelum mahaisswa melakukan tes, mahasiswa harus telah mendaftar secara online untuk mendapatkan tempat dan waktu tes online, ujian komprehensif dilakukan selama 50 menit untuk 100 soal . pelaksanaan ujian terekan oleh kamera cctv, dan surat keterangan lulus dikeluarkan oleh Prodi sesuai surat dari kepala Laboratorium Komputer Sejarah dengan nilai kelulusan lebih dari 80. Pelaksanaan tes komprehensif ini merupakan salah satu upaya prodi untuk meningkatkan mutu prodi guna menjawab tantangan revolusi industri 4.0 yang salah satunya menggantikan yang manual menjadi berbasis data dan komputer based dengan pemanfaatan internet dan media komunikasi informasi.

\section{Simpulan}

Arus globalisasi tidak dapat dihindari, kemajuan teknologi semakin canggih menuntut manusia untuk terus berkembang dan mampu menghadapi tantangan dengan arif dan bijaksana. Tidak semua kemajuan teknologi berdampak positif dalam bidang pendidikan, namun harus ada upaya keras dari perguruan tinggi untuk mampu melakukan perubahan dalam era revolusi industri 4.0 ini. Dengan demikian dapat dikatakan bahwa usaha penjaminan mutu Prodi Pendidikan Sejarah Fakultas Ilmu Sosial Universitas Negeri Medan merupakan usaha sadar dari institusi untuk meningkatkan kualitas prodi dalam menghadapi tantangan revolusi industri 4.0.

\section{DAFTAR PUSTAKA}

Badan Pengembangan SDM dan Penjamin Mutu Pendidikan, 2013

Buchori, Achmad. 2012. Pengembangan Media E-lErning pada Mata Kuliah Komputasi Di

Perguruan Tinggi Jurnal JMP : Volume 4 Nomor 1, Juni 2012, hal. 147 - 159 
(file:///F:/lemlit\%202018/13-achmad_buchori.pdf) diakses pada tanggal $12 \mathrm{mei}$ 2018

Darmawan, Deni. 2016. Pengembangan E- Learning Teori dan Desain. Bandung : PT Remaja Rosdakarya

http://www.ristekdikti.go.id 8.

http://www.ristekdikti.go.id/pengembangan-iptek-dan-pendidikan-tinggi-di-erarevolusi-industri4-0

http://sumberdaya.ristekdikti.go.id/index.php/2018/01/30/era-revolusi-industri-4-0-saatnyagenerasi-millennial-menjadi-dosen-masa-depan/

https://www.unimed.ac.id/2016/09/13/unimed-susun-standar-perkuliahan-kurikulum-kkni/ Rusman. 2016. Model - Model Pembelajaran Mengembangkan Profesionalisme Guru. Jakarta : PT RajaGrafindo Persada

Wati, Ega Rima. 2016. Ragam Media Pembelajaran. Jakarta: Kata Pena. 